\title{
Evaluation of barriers between anterior and posterior compartments during Nd:YAG capsulotomy in diabetic patients
}

This article was published in the following Dove Press journal:

Clinical Ophthalmology

3 March 2014

Number of times this article has been viewed

\section{Pelin Özyol \\ Erhan Özyol}

Department of Ophthalmology, Ünye State Hospital, Ordu, Turkey
Correspondence: Pelin Özyol Ünye State Hospital, Department of Ophthalmology, Ordu, Turkey Email pelingesoglu@yahoo.com.tr

\section{Dear editor}

We have read the article by Awan et $\mathrm{al}^{1}$ with great interest. We want to add a few comments on the paper.

Neodymium-doped yttrium-aluminum-garnet (Nd:YAG) laser is needed to revert the deficiency of visual acuity caused by posterior capsule opacification. However, this procedure involves an alteration of ocular compartments that increases the risk of the patient suffering severe posterior segment pathologies. The space between the posterior capsule of the lens and the anterior hyaloid membrane is defined as Berger space. It is thought to act as a mechanical barrier separating the physiological and functional anterior portion of the eye from the posterior portion of the eye. ${ }^{2}$ Any factor affecting the posterior capsule may have a potential effect on the anterior hyaloid membrane, due to the close anatomical relationship during Nd:YAG laser capsulotomy or phacoemulsification.

We know that the anterior hyaloid face is an important barrier for both the anterior and posterior compartments of the eye. Not only the total energy used, but also the deterioration of the anterior hyaloid face related to the YAG laser beam, may increase posterior segment complications. ${ }^{3}$ Besides this, the mechanical effect of vitreous humor due to vitreous disruption, anterior hyaloid face destruction, or release of mediators like prostaglandins are all factors involved in the pathogenesis of cystoid macular edema. ${ }^{4}$ We want to emphasize the importance of the anterior hyaloid face integrity. In practice, pulse energy, pulse number, size and centration of capsulotomy, and improvement in visual acuity are the surgeon's priorities. In fact, during laser procedure, anterior hyaloid membrane integrity or retinal complications don't come to mind. Therefore, as this technique is not free from possible complications, it should not be based on visual acuity improvement. ${ }^{3}$ In addition to retinal complications, the quality of vision during diurnal activities should also be considered. Anterior hyaloid damage or vitreous disruption, even with no serious retinal complications, may affect visual quality in patients. We therefore think it would be better to evaluate not only an increase in visual acuity but also the quality of vision.

The second point that we would like to discuss is the evaluation of vascular endothelial growth factor (VEGF) in diabetic patients who underwent Nd:YAG laser capsulotomy. VEGF, a potent angiogenic factor, is expressed at high levels in the retina of diabetic patients, resulting in a marked increase in concentration in the vitreous humor. We know that cataract extraction and vitrectomy may facilitate the 
progression of neovascular glaucoma. ${ }^{5}$ The deterioration of the anterior hyaloid face due to laser beam may cause a passage formation from posterior to anterior segment. In other words, weakening of the barriers may facilitate the VEGF transport from posterior to anterior segment through the pupillary area, and may enhance iris neovascularization and progression of glaucoma. As a result, although there is no study evaluating the behavior of VEGF in eyes with anterior hyaloid damage due to laser beam, we think that maximum attention must be given to protecting the anterior hyaloid face integrity, especially for diabetic patients.

\section{Disclosure}

The authors have no financial or proprietary interest in any material mentioned in this communication.

\section{References}

1. Awan MT, Khan MA, Al-Khairy S, Malik S. Improvement of visual acuity in diabetic and nondiabetic patients after Nd:YAG laser capsulotomy. Clin Ophthalmol. 2013;7:2011-2017.

2. Steinert RF, Puliafito CA, Kumar SR, Dudak SD, Patel S. Cystoid macular edema, retinal detachment, and glaucoma after Nd:YAG laser posterior capsulotomy. Am J Ophthalmol. 1991;112(4):373-380.

3. Özyol E, Özyol P, Doğanay-Erdoğan B, Onen M. The role of anterior hyaloid face integrity on retinal complications during Nd:YAG laser capsulotomy. Graefes Arch Clin Ophthalmol. 2014;252(1):71-75.

4. Hayashi K, Hayashi H, Nakao F, Hayashi F. Correlation between posterior capsule opacification and visual function before and after Neodymium:YAG laser posterior capsulotomy. Am J Ophthalmol. 2003;136(4):720-726.

5. Wakabayashi Y, Usui Y, Okunuki Y, et al. Intraocular VEGF level as a risk factor for postoperative complications after vitrectomy for proliferative diabetic retinopathy. Invest Ophthalmol Vis Sci. 2012;53(10): 6403-6410.
Clinical Ophthalmology

\section{Publish your work in this journal}

Clinical Ophthalmology is an international, peer-reviewed journal covering all subspecialties within ophthalmology. Key topics include: Optometry; Visual science; Pharmacology and drug therapy in eye diseases; Basic Sciences; Primary and Secondary eye care; Patient Safety and Quality of Care Improvements. This journal is indexed on

Submit your manuscript here: http://www.dovepress.com/clinical-ophthalmology-journal

\section{Dovepress}

PubMed Central and CAS, and is the official journal of The Society of Clinical Ophthalmology (SCO). The manuscript management system is completely online and includes a very quick and fair peer-review system, which is all easy to use. Visit http://www.dovepress.com/ testimonials.php to read real quotes from published authors. 